\title{
Dentipellis fragilis and Steccherinum oreophilum: Finnish records of hydnaceous fungi
}

\author{
TUOMO NIEMELÄ and REIMA SAARENOKSA
}

\begin{abstract}
NIEMELÄ, T. \& SAARENOKSA, R. 1985: Dentipellis fragilis and Steccherinum oreophilum: Finnish records of hydnaceous fungi. - Karstenia 25: 70-74.

Dentipellis fragilis (Pers.: Fr.) Donk is reported from four localities in southern Finland. Two earlier Finnish records also exist and a record from the adjacent U.S.S.R. The species is briefly described, and its ecology and general distribution are reviewed. Steccherinum oreophilum Linds. \& Gilb. is reported as new to Finland, and its known occurrence in Europe and North America is summarized. Distribution maps are presented and both species are illustrated. The delimitation of the genera Irpex, Steccherinum, Schizopora and Junghuhnia is considered to deserve a thorough revision.
\end{abstract}

Tuomo Niemelä and Reima Saarenoksa, Department of Botany, University of Helsinki, Unioninkatu 44, SF-00170 Helsinki, Finland

\section{Introduction}

The wood-inhabiting, hydnaceous fungi include numerous corticiaceous species, which are rather poorly known in Finland. The pileate and more robust representatives of the group were recently studied and illustrated by Koski-Kotiranta and Niemelä (1983). In this paper the occurrence of two additional, rare small-sized species is treated. Modern descriptions are available for them both: we will merely provide some further notes, and concentrate on ecological and distributional aspects.

The field observations and checking of the herbarium material were mainly the work of Reima Saarenoksa; while Tuomo Niemelä is responsible for the taxonomical and bibliographical survey. The collected material is deposited in the Botanical Museum of the University of Helsinki $(\mathrm{H})$ and the reference herbarium of the senior author (T.N.).

\section{Dentipellis fragilis}

The taxonomy and nomenclature of Dentipellis fragilis (Pers.: Fr.) Donk was discussed by Donk (1962).

The species is characterized by resupinate fruit bodies, which have a thin subiculum and $3-6 \mathrm{~mm}$ long, soft (fresh) to fragile (dry) spines. The margin is soft, well delimited and slightly thicker than the subiculum; its extensions become easily detached from the substrate and may then resemble minute, thin caps. Fruit bodies often emerge on the same trunk in many successive years.

The hyphal system is monomitic, with fragile, fibulate generative hyphae, which are negative in Melzer's reagent, but cyanophilous if studied in adequately thin sections. The hymenium consists of narrow basidia and basidioles, abundant gloeocystidia, and projecting, thin-walled cystidioles, which often have moniliform constrictions at their apices. The spores are subglobose, acyanophilous but strongly amyloid, $4-5.5 \mu \mathrm{m}$ in diam. They are rather thick-walled and ornamented, though appearing smooth if not studied carefully under a phase contrast microscope or in Melzer's reagent. Their warted surface structure is clearly shown by the SEM picture of Tortić and Jelić (1977).

More detailed descriptions can be found in Neubert (1969), Jahn (1969), Nikolaeva (1961), Domański (1975) and Strid (1983). Coloured photograhs of $D$. fragilis have been published by Knudsen \& Pedersen (1984) and Ryman \& Holmåsen (1984). Its microstructure, on the other hand, has not been adequately illustrated; the species is not included in the flora of the Corticiaceae by John Eriksson and others (cf. Hjortstam 1984).

D. fragilis is associated with white-rot. It grows characteristically on rather thick, fallen trunks of deciduous trees, in Finland on Acer tataricum, Alnus, Prunus padus and Sorbus aucuparia. The habitats recorded are moist and shady thickets or grass-herb forests, and the species apparently favours a moist microclimate and warm summers. The collection on A. tataricum was made from an exceptional place, a standing, living tree in the Botanical Garden of the University of Helsinki. The maple-tree is old, weak and leaning, and fruit bodies have appeared in many years on a decorticated depression, where a big branch has broken off, ca. $1 \mathrm{~m}$ above the ground. This site is also in continuous shadow. A. tataricum is not indigenous to Finland.

\section{Distribution}

The species was wrongly reported (as Dryodon fragile) by Laurila (1939) from Satakunta: Siikainen in western Finland, and the record was included in the distribution map of Ryman and Holmåsen (1984). The misidentification was revealed by Mr. Heikki 

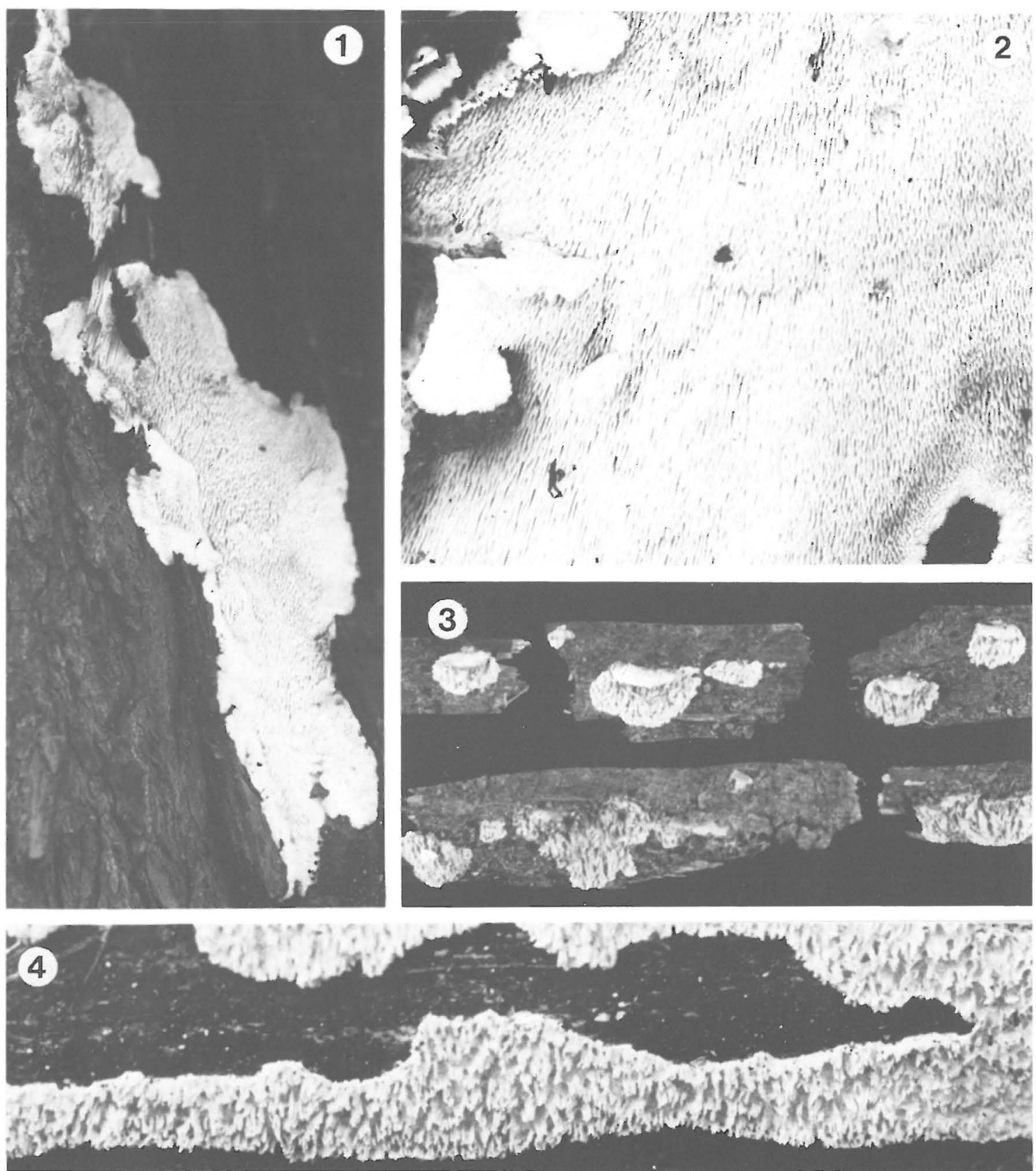

Figs. 1-4. Two hydnaceous fungi. -1 : Dentipellis fragilis, $\times 1$ (Niemelä 2330). -2 : D. fragilis, $\times 2$ (Niemelä 1389). -3 : Steccherinum oreophilum, dry effused-reflexed specimens, $\times 1.5$ (Saarenoksa 20484). - 4: S. oreophilum, fresh, resupinate fruit bodies, X 3.5 (Niemelä $3214 \&$ Saarenoksa 5985).

Kotiranta, who checked the specimen (in H-LA) and showed it to represent Radulodon erikssonii Ryv., another resupinate, hydnaceous fungus.

Karsten (1889) reported 'Hydnum niveum Pers.' from three localities in southern Finland, viz., Varsinais-Suomi: Turku, Uusimaa: Porvoo and Etelä-
Häme: Tammela. Only a specimen from the lastmentioned locality was found, and this was confirmed to represent $D$. fragilis. Karsten (1889) described the species as white to yellowish, resupinate, with globose spores $4-5 \mu \mathrm{m}$ in diam and we regard the other reports as reliable as well: they are indicated with 

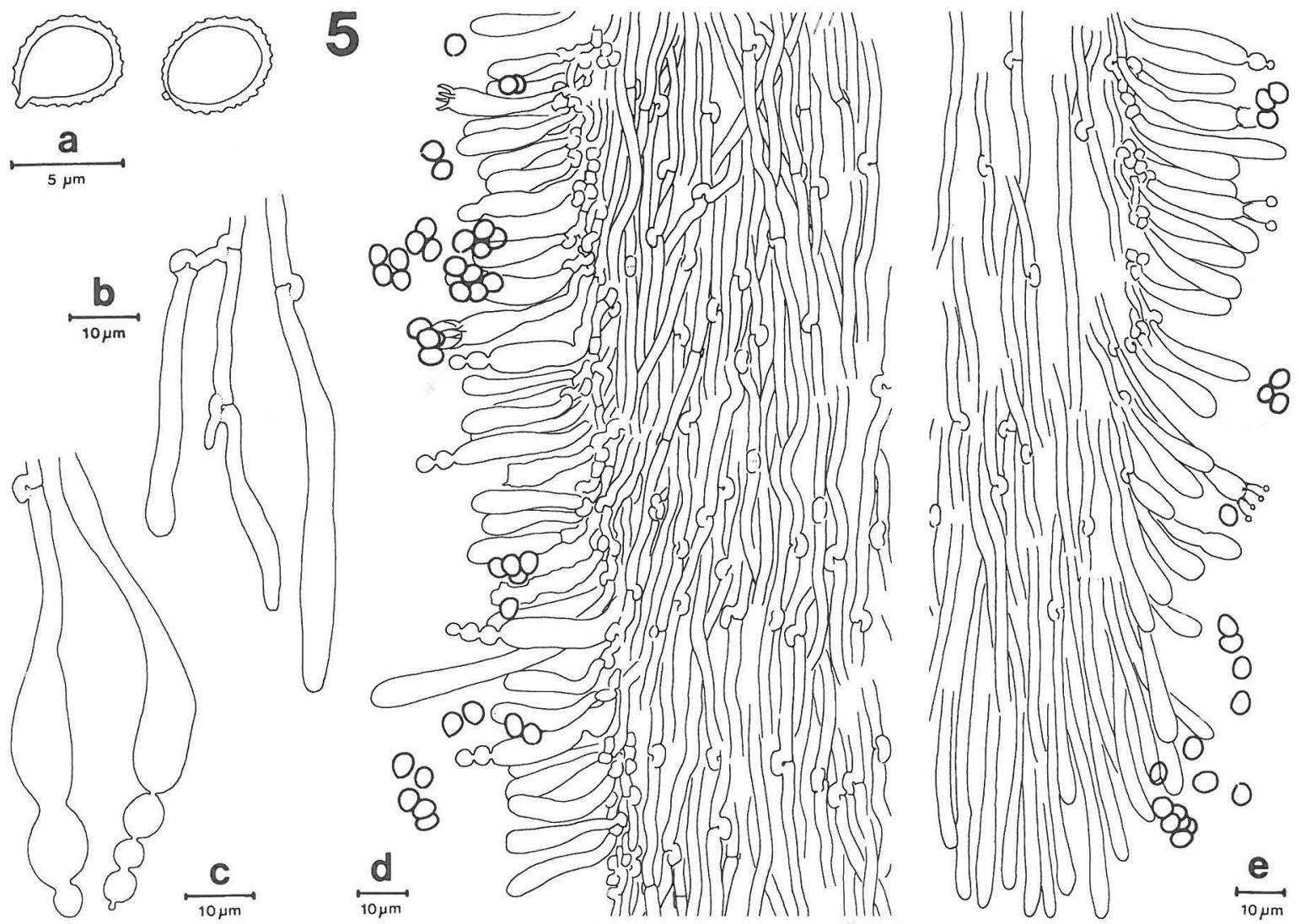

Fig. 5. Dentipellis fragilis. a) spores, b) gloeocystidia, c) cystidioles, d) spine in vertical section, e) spine apex. Drawn in Melzer's reagent (Niemelä 2330).

smaller dots on the map.

Two newer collections from Uusimaa: Hanko and Helsinki were included in the study of Koski (1983); the latter was published by Niemelä and Erkkilä (1983). The records by Reima Saarenoksa have not been published before.

Høgholen and Ryvarden (1977) reported the species as new to Norway. The distribution in Denmark was mapped by Knudsen and Pedersen (1984), in Sweden by Ryman (1984) and in the Estonian S.S.R. by Nikolaeva (1961). Thesleff (1920, 'Hydnum niveum') found the species in the surroundings of Vyborg, now belonging to the U.S.S.R.: that locality is included in our map. Mazelaitis (1976) reported it in the Lithuanian S.S.R. When these records and our new information are combined, it can be cocluded that in Noth Europe the species is mainly restricted to the Hemiboreal and Temperate zones, which comprise a southern vegetational element, e.g., including the natural occurrence of Quercus robur. The distribution is slightly continental, i.e., south-eastern: the species seems to be absent from the western parts of Norway and Denmark. It does not occur in the British Isles (Knudsen \& Pedersen 1984).

In Sweden D. fragilis is regarded as rare but not endangered (Ryman 1984). The localities in Finland should probably be given some kind of protection.

The species has a wide distribution in Central Europe, having been reported from Austria, France, Czechoslovkia, the Federal Republic of Germany, the German Democratic Republic, Poland, Yugoslavia and the western U.S.S.R. (Bourdot \& Galzin 1928, Nikolaeva 1961, Jahn 1969, Neubert 1969, Zerova et al. 1972, Tortić \& Jelić 1977, Bujakiewicz 1979, Dietrich 1982). It seems to be mostly scattered, but may be locally abundant in Central and South European low-montane beech forests. The distribution extends eastwards through the southern Soviet Union (map in Nikolaeva 1961; StepanovaKartavenko 1967) as far as the Sikhote-Alin Mts. in the Soviet Far East (Gordienko 1979). Hjortstam and Ryvarden (1984) reported it from Nepal.

\section{Specimens examined}

Finland. Uusimaa: Helsinki, Univ. Botanical Garden, Acer tataricum, 1981 Niemelä 2330 (T.N., also observed in 1982, 1984, 1985). Hanko, Tvärminne Zool. Sta., Sorbus aucuparia, 1981 Väinölä (H). Sipoo, Hindsby, Prunus padus, 1984 Saarenoksa 30084, 46384 (H). Etelä-Häme: Tammela, Mustiala, Alnus, 1882 Karsten 1872 (H). Sweden. Västergötland: Göteborg, Botanical Garden, Alnus incana, 1970 Niemelä (T.N). U.S.S.R. Leningrad Region: Vyborg, 
Liimatta, Betula, 1892 Thesleff (H). Poland. Woj. krakowskie: Zawoja, Babiogórski Park Narodowy, Fagus sylvatica, 1978 Niemelä 1389 (T.N.).

\section{Steccherinum oreophilum}

The identity of Steccherinum oreophilum Linds. \& Gilb. has been clarified only recently (Lindsey \& Gilbertson 1977). It has most probably often been confused with Irpex lacteus (Fr.: Fr.) Fr., which is very similar in habit.

The fruit bodies of $S$. oreophilum are very smallsized, a character evident from earlier descriptions, too. In our material they were seldom over $10 \mathrm{~mm}$ wide, projecting $2-5 \mathrm{~mm}$, effused-reflexed or resupinate. They appear as separate, roundish patches on thin bark or bare wood. The overall colour is cream to straw, with an ochraceous tint in the dry hymenophore. The surface is not tomentose (as in Irpex), but glabrous and with silky lustre near the margin and more greyish tone close to the wood. The context and subiculum are extremely thin, under 0.5 $\mathrm{mm}$. The spines are irregularly flattened, $0.5-2 \mathrm{~mm}$ long, and in the marginal areas form a sinuous, almost poroid structure.

The hyphal system is dimitic. The generative hyphae are thin-walled and have clamp connections; the skeletal hyphae are thick-walled, non-septate, unbranched and weakly cyanophilous. In the spine apices the hyphae have swollen tips. The hymenium consists of long $(40-60 \times 6-9 \mu \mathrm{m})$, deep-rooting cystidia, which are especially numerous at the spine apices, pointed and heavily encrusted. The spores are ellipsoid, $6-6.8 \times 3 \mu \mathrm{m}$, negative in Melzer's reagent, but turning faint blue in Cotton Blue, due to staining of the plasma.

The species differs from Irpex lacteus in its smaller size, glabrous pileus, the presence of clamp connections and slightly larger spores. In $S$. oreophilum the cystidia are more tapering and carrotformed, while in I. lacteus they are blunt and less heavily encrusted.

An excellent illustration of the microstructure was

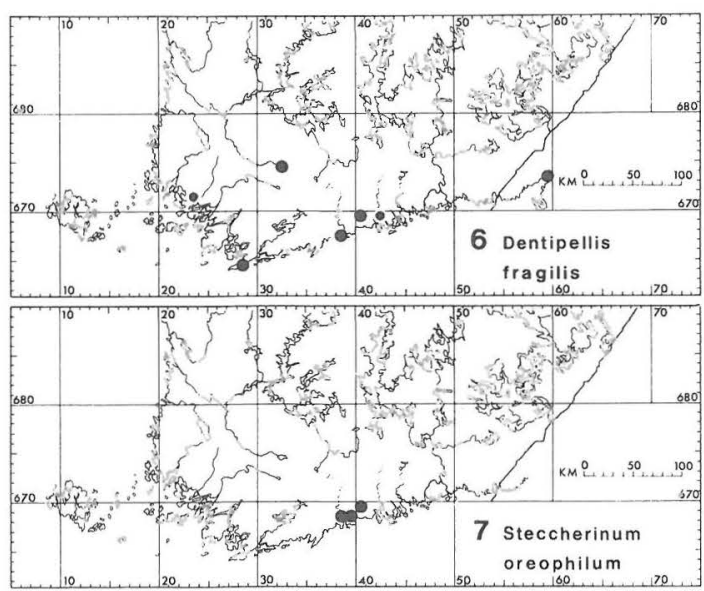

Figs. 6-7. Dentipellis fragilis and Steccherinum oreophilum in Finland and adjacent U.S.S.R. Small dots refer to unverified literature records. published by Eriksson et al. (1984). Further figures of both the macroscopic and microscopic characters have been presented by Lindsey \& Gilbertson (1977, 1978), Ginns (1982) and David \& Boidin (1984).

\section{Distribution and ecology}

$S$. oreophilum was described from North America. The northernmost records come from the Northwest Territories, Alberta, Québec and Ontario in Canada, and its range extends southwards to Arizona and Utah in the U.S.A. (Lindsey \& Gilbertson 1977, 1978, Gilbertson et al. 1979, Ginns 1982).

The presence of the species in Europe was established only very recently. David and Boidin (1984) reported it from France. At almost the same time Eriksson et al. (1984) reported it from the German Democratic Republic, and Kotlaba (1984) from six localities in Czechoslovakia. Our record is the first from North Europe (cf. Hjortstam 1984).

There may, however, also be older notes on the species. The presence or absence of clamp connections in Irpex lacteus has long puzzled European mycologists, and it seems likely that many of them had also encountered $S$. oreophilum. From time to time the name $I$. lacteus has been used for a taxon with clamped hyphae (i.e., S. oreophilum), and I. tulipiferae (Schw.) Schw. for a clampless taxon (i.e., I. lacteus s.str.). The reference of Jahn (1969) to the clamped and clampless forms of I. lacteus, for instance, may perhaps be due to the presence of $S$. oreophilum in his material (from the Federal Republic of Germany), and this may also explain the observations of Maas Geesteranus (1963) from the Netherlands. It is quite possible that an older European name could be found for S. oreophilum amongst the long list of synonyms reported for $I$. lacteus (Donk 1974).

The Finnish collections were made in moist grassherb forests or thickets, with predominantly deciduous trees. The fruit bodies emerge mostly on fallen branches or on the crown of fallen trees. A humid microclimate is evidently necessary: a collection was made on a tree fallen over a brook. The wood under the fruit bodies is very hard, making collecting difficult.

In Europe $S$. oreophilum has been reported from Fagus sylvatica, Populus tremula, Salix aurita, $S$. caprea and Cytisus (Sarothamnus) scoparius; Populus is by far the commonest host. The American collections are from Populus tremuloides (most records), Prunus sp. and Tilia americana.

\section{Specimens examined}

Finland. Uusimaa: Helsinki, Viikki, Populus tremula, 1983 Saarenoksa $56283(\mathrm{H}), 1985$ Saarenoksa 4185, $5985(\mathrm{H})$, Niemelä 3214 (T.N.), Salix caprea, 1985 Niemelä 3216 (T.N.); Mustavuori, Salix, 1985 Saarenoksa 4085 (H, T.N.). Sipoo, Hindsby, P. tremula, 1983 Saarenoksa $46683(\mathrm{H})$ 1984 Saarenoksa 20484 (H, T.N.), S. caprea, 1985 Saarenoksa $10085(\mathrm{H})$.

The collections of Irpex lacteus and Cerrena unicolor in herb. $\mathrm{H}$ were checked for this species, but no further specimens were detected.

\section{Relationships to other genera}

The very fact that $S$. oreophilum is easily confused with $I$. lacteus shows that the differences between 
Steccherinum and Irpex are extremely small. In his extensive studies, Maas Geesteranus (1963, 1974) came to the conclusion that the only clear difference between these genera is the presence or absence of clamp connections; on many occasions he implied that the two genera could well be united. The acceptance of two clampless species in Steccherinum by Eriksson et al. (1984) has invalidated this one differentiating character. Unfortunately, Irpex is a sanctioned generic name (though Steccherinum is older), and the mergence of the genera would result in numerous undesirable name changes.

Steccherinum also seems to have affinities with Schizopora, especially S. paradoxa (Schrad.: Fr.) Donk. The hyphal structures are rather similar, especially in the trama, but $S$. paradoxa does not have heavily encrusted cystidia. However, Steccherinum alaskense Lindsey \& Gilb. (Lindsey \& Gilbertson 1979) also lacks encrusted cystidia.

The division between Steccherinum and the poroid genus Junghuhnia has long been known to be vague. For instance, S. ochraceum (Pers.: Fr.) Gray and Junghuhnia nitida (Pers.: Fr.) Ryv. are microscopically almost indistinguishable, the sole distinct difference lying in the hymenophoral configuration (hydnoid $v s$. poroid). Lindsey \& Gilbertson (1977) report that $S$. oreophilum often has pores in the fruit body margins, which makes this difference unreliable. Moreover, in many species of Junghuhnia the pores tend to split with age and drying, so that the hymenophore becomes almost denticulate.

All these genera consist of white-rot producing species. Together they make up a complex which badly needs a thorough revision. Their mergence in one genus is unlikely to be a really satisfactory solution, but better criteria are required to keep the genera separate.

Acknowledgement. We thank Mr. Heikki Kotiranta, M.Sc., for sorting herbarium material and detecting the misidentification of a specimen as Dentipellis fragilis.

\section{References}

Bourdot, H. \& Galzin, A. 1928: Hyménomycètes de France. -761 pp. Sceaux.

Bujakiewicz, A. 1979: Grzyby Babiej Góry 1. Mikoflora lasów. - Acta Mycol. 15: 213-294.

David, A. \& Boidin, J. 1984: Presence en Europe du Steccherinum oreophilum (Basidiomycetes) décrit d'Amerique du Nord. - Mycotaxon 21: 427-430.

Dietrich, W. 1982: Besonderheiten der Pilzflora des Westerzgebirges. - Boletus 6: 1-12.

Domański, S. 1975: Basidiomycetes (Podstawczaki), Aphyllophorales (Bezblaszkowe) 2. - In: Domański, S. \& Stankówna, Z. (eds.), Mala Flora Grzybów 2: 1-318. Warszawa \& Kraków.

Donk, M. 1962: Notes on resupinate Hymenomycetes 6. Persoonia 2: 217-238.

- 1974: Check list of European polypores. - 469 pp. Amsterdam \& London.

Eriksson, J., Hjortstam, K. \& Ryvarden, L. 1984: The Corticiaceae of North Europe 7. Schizopora to Suillosporium. - Pp. 1281-1889. Oslo.

Gilbertson, R., Goldstein, D. \& Lindsey, J. 1979: Additions to the check list and host index for Arizona wood-rotting fungi. - J. Arizona-Nevada Acad. Sci. 14: 81-87.

Ginns, J. 1982: Steccherinum oreophilum: cultural characters and occurrence in North America. Mycologia 47: 20-25.
Gordienko, P. 1979: Vlianie sostoania substrata na rasselenie derevorazrušayužih gribov $v$ hvojno-širokolistvennyh lesah Sihote-Alina. - Mikol. Fitopatol. 13: 421-428.

Hjortstam, K. 1984: Corticiaceous fungi of northern Europe, check-list of the species in the Nordic countries. Windahlia 14: 1-29.

Hjortstam, K. \& Ryvarden, L. 1984: Some new and noteworthy Basidiomycetes (Aphyllophorales) from Nepal. - Mycotaxon 20: 133-151.

Høgholen, E. \& Ryvarden, L. 1977: Noen nye sopper for Norge. - Blyttia 35: 15-17.

Jahn, H. 1969: Einige resupinate und halbresupinate Stachelpilze in Deutschland. - Westfäl. Pilzbriefe 7: $113-144$.

Karsten, P. 1889: Kritisk öfversigt af Finlands basidsvampar (Basidiomycetes, Gastero- \& Hymenomycetes). - Bidr. Känned. Finlands Nat. Folk 48: 1-470.

Knudsen, H. \& Pedersen, A. 1984: De danske koralpigsvampe. - Svampe 10: $91-99$.

Koski, S. 1983: Puissa kasvavista orakkaista Suomessa. - 63 pp. Unpubl. Cand. Phil. Thesis, Dept. of Botany, Univ. Helsinki.

Koski-Kotiranta, S. \& Niemelä, T. 1983: Puitten orakkaat. -Sienilehti 35: 99-116.

Kotlaba, F. 1984: Zeměpisné rozšiření a ekologie chorosu (Polyporales s. 1.) v Ceskoslovensku. - 194 pp. Praha.

Laurila, M. 1939: Basidiomycetes novi rarioresque in Fennia collecti. - Ann. Bot. Soc.-Bot. Fenn. Vanamo 10 (1): $1-24$.

Lindsey, J. \& Gilbertson, R. 1977: A new Steccherinum (Aphyllophorales, Steccherinaceae) on quaking aspen. - Mycologia 69: 193-197.

- 1978: Basidiomycetes that decay aspen in North America. - 406 pp. Vaduz.

- 1979: A new Steccherinum (Aphyllophorales, Steccherinaceae) from Alaska. - Mycologia 71: 12641267.

Maas Geesteranus, R. 1963: Hyphal structures in Hydnums 4. - Kon. Nederl. Akad. Wetensch. Proc. (Ser. C) 66(5): 447-457.

- 1974: Studies in the genera Irpex and Steccherinum. Persoonia 7: 443-581.

Mazelaitis, J. 1976: Lietuvos TSR afiloforiečiu eilés grybai. -379 pp. Vilnius.

Neubert, H. 1969: Dentipellis fragilis (Pers. ex Fr.) Donk, ein resupinater Stachelbart. - Westfäl. Pilzbriefe 7: 105107.

Niemelä, T. \& Erkkilä, R. 1983: Käävät Helsingin yliopiston kasvitieteellisessä puutarhassa. - In: Jalas, J. (ed.), Kasvitieteellisen puutarhan eliömaailmaa 1: 83-93. Helsinki.

Nikolaeva, T. 1961: Ežovikovye griby. - In: Savič, V. (ed.), Flora Spor. Rast. SSSR 6(2): 1-432. Moskva \& Leningrad.

Ryman, S. 1984: Dentipellis fragilis (Pers. ex Fr.) Donk. -In: Ingelög, T., Thor, G. \& Gustafsson, L. (eds.), Floravård i skogsbruket 2, artdel: 344 . Jönköping.

Ryman, S. \& Holmåsen, I. 1984: Svampar, en fälthandbok. -718 pp. Stockholm.

Stepanova-Kartavenko, N. 1967: Afilloforovye griby Urala. $-293 \mathrm{pp}$. Sverdlovsk.

Strid, A. 1983: Svenska taggsvampar 3. Vedväxande arter. -Jordstiärnan 4: 16-28.

Thesleff, A. 1920: Studier öfver basidsvampfloran i sydöstra Finland. - Bidr. Kännedom Finlands Nat. Folk 79(1): $1-140$.

Tortić, M. \& Jelić, M. 1977: The family Hericiaceae and the genus Climacodon in Yugoslavia. - Acta Bot. Croat. 36: $153-164$

Zerova, M., Radzievśkij, G. \& Sevčenko, S. 1972: Basidiomiceti 1, ekzobazidial'ni, afiloforal'ni, kantarelal'ni. - In: Zerov, D. (ed.), Viznačnik gribiv Ukrajni 5: 1-240. Kiev.

Accepted for publication on March 5, 1985 